\title{
INFLUENCE OF THE CONDITION OF THE AIRFIELD PAVEMENT STRUCTURES ON THE OPERATION SAFETY OF AIRCRAFT
}

\author{
WPEYW STANU NOŚNOŚCI KONSTRUKCJI \\ NAWIERZCHNI LOTNISKOWYCH NA \\ BEZPIECZEŃSTWO OPERACJI LOTNICZYCH \\ STATKÓW POWIETRZNYCH
}

\author{
Mariusz Wesołowski, Piotr Barszcz, Krzysztof Blacha
}

Air Force Institute of Technology

Instytut Techniczny Wojsk Lotniczych

\begin{abstract}
The structure of the airfield pavement is a set of layers, whose task is to take over and transfer loads from moving aircraft to a ground subsoil in a safety manner. Airfield pavements are designed for a specific period of operation, assuming the forecasted intensity and the structure of the air traffic. The safety of air operations executed by the aircraft on airfield pavements depends primarily on the condition of their structure's load capacity. In order to assess the load capacity of airfield pavements, the method ACN-PCN, which was introduced by the International Civil Aviation Organization ICAO and according to which the load capacity of the airfield pavement is expressed with the PCN index, is applied.
\end{abstract}

Keywords: load bearing capacity, airfield pavement, safety, air operations, aircraft

Streszczenie: Układ konstrukcyjny nawierzchni lotniskowej to zespót warstw, których zadaniem jest przejęcie $i$ przeniesienie $w$ bezpieczny sposób na podtoże gruntowe obciażen pochodzacych od poruszajacych się statków powietrznych. Nawierzchnie lotniskowe sa projektowane na określony okres eksploatacji przy zatożeniu prognozowanego natężenia i struktury ruchu lotniczego. Bezpieczeństwo wykonywania operacji lotniczych przez statki powietrzne na nawierzchniach lotniskowych zależy przede wszystkim od stanu nośności ich konstrukcji. Do oceny nośności nawierzchni lotniskowych stosuje sie metode ACN-PCN, która została wprowadzona przez Organizacje Międzynarodowego Lotnictwa Cywilnego ICAO $i$ wedtug której nośność konstrukcji nawierzchni lotniskowych jest wyrażana wskaźnikiem PCN.

Stowa kluczowe: nośność, nawierzchnia lotniskowa, bezpieczeństwo, operacje lotnicze, statek powietrzny 
Influence of the condition of the airfield pavement structures on the operation...

Wpływ stanu nośności konstrukcji nawierzchni lotniskowych na bezpieczeństwo...

\section{INFLUENCE OF THE CONDITION OF THE AIRFIELD PAVEMENT STRUCTURES ON THE OPERATION SAFETY OF AIRCRAFT}

\section{Introduction}

An airfield pavement is a designated and properly prepared surface of an airport functional element (AFE) fulfilling a specific function in the execution of the air operations, i.e. designed for traffic, parking and maintenance of aircraft. In most cases, the structure of an airfield pavement is a set of layers, whose task is to take over and transfer loads from travelling aircraft and helicopters to ground subsoil in a way that ensures its determined durability.

Airfield pavements can be divided into two groups [5]:

- natural pavements: land, grass, and turf;

- artificial pavements.

One of the main operational features of the airfield pavements is its load capacity understood as the ability of a structure to transfer loads from aircraft in specified time. In accordance with the requirements set by the International Civil Aviation Organisation $(I C A O)$, the load capacity of the airfield pavement structure is determined with the ACN-PCN method [8]. The load capacity of pavements depends not only on the load of the aircraft but also on many external factors, including among others weather conditions [4], which could include:

- number of air operations (loads of the aircraft) taking place or planned on the said pavement;

- cross-section of pavement structure - thickness of particular structural layers;

- concrete's bending strength;

- concrete modulus of elasticity;

- Poisson's coefficient of the airfield pavement's structural layers and ground subsoil;

- type, density, and moisture of the ground subsoil;

- ground subsoil's load capacity;

- temperature during executed field tests.

The full analysis of the airfield pavement requires identification of physicochemical parameters of the material of its particular structural layers and ground subsoil. The identification should be executed in a manner taking into account actual conditions of the pavement's operation because it has a significant impact on determining the airfield pavements' load capacity due to the fact that the manner of transferring the load by the aircraft to the ground subsoil is dependent on the type of an airfield pavement structure. Depending on its type and the manner of operation, to express the nature of the aircraft's impact on the pavement, appropriate mathematical models are applied. 


\section{Assumptions of ACN-PCN method}

The assessment of the airfield pavement's load capacity is currently carried out with the ACN-PCN method, where the Aircraft Classification Number $(A C N)$ expresses the relative influence of the aircraft on the airfield pavement when the standard load capacity of the ground subsoil is determined. ICAO defined the procedure for determining the $\mathrm{ACN}$, which assumes that the standard volumes in the process of its calculation are:

- the pressure in the tire of a single main strut wheel equal to $1.25 \mathrm{MPa}$;

- permissible bending stresses in a concrete slab (for rigid pavements) equal to $2.75 \mathrm{MPa}$;

- permissible number of loads in the case of flexible pavements;

- load capacity of the ground subsoil, described with the subsoil reaction coefficient $k$ for the rigid pavements and with the CBR index for flexible pavements.

The ACN is specified with the formula:

$$
A C N=2 \cdot P_{r}
$$

where:

$P_{r}$ - equivalent load in thousands of kilograms of such a value that the pavement's thickness necessary for its transfer is equal to the thickness defined as for the actual load: $P_{r}=\pi \cdot q \cdot a^{2}$;

$q$ - uniform load with an intensity of $1.25 \mathrm{MPa}$, distributed on the circular area with radius $a$.

The load capacity of the rigid pavement is influenced by: shape and dimensions of concrete slabs, the manner of their adhesion to the ground subsoil and the concrete's strength parameters. The load capacity of the flexible pavement structure depends on the number and thickness of layers, as well as the physicomechanical properties of these layers' materials. Rigidity moduli of particular structural layers, the corresponding Poisson's coefficient values and inter-layer connections' condition, cracks in the pavement layers, water penetrating the structure and the ground subsoil, as well as the temperature of the asphalt layers are particularly significant. The load capacity of the ground subsoil is an important factor in determining the ability of the pavement to take the loads. The aeroplane ACNs are determined taking into account the standard values of the ground subsoil's load capacity. For each aircraft, the ACN is a set of numbers depending on the type of airfield pavement's structure (rigid and flexible) and the load capacity of the ground subsoil. The Pavement Classification Number $(P C N)$ expresses the load capacity of the airfield pavement for a limited number of aircraft's travels with the $\mathrm{ACN}=\mathrm{PCN}$. It is equivalent to $1 / 500$ of the allowable load (expressed in kilograms of weight) applied to the pavement via a single wheel with a standard pressure equal to $1.25 \mathrm{MPa}$. 
Influence of the condition of the airfield pavement structures on the operation... Wptyw stanu nośności konstrukcji nawierzchni lotniskowych na bezpieczeństwo...

According to the adopted findings, in the ACN-PCN method, the airfield pavement load capacity is described by a group of symbols representing various structure parameters and informing about the method of determining the PCN, e.g. PCN $48 / \mathrm{R} / \mathrm{B} / \mathrm{X} / \mathrm{T}$. The detailed manner of interpretation of the above-mentioned notation is shown in Table 1 .

Table 1. PCN index interpretation manner

\begin{tabular}{|c|c|c|c|c|c|}
\hline 1 & Dimensionless PCN & & & & \\
\hline \multirow{2}{*}{2} & \multirow{2}{*}{ Pavement type } & $\mathbf{R}$ & \multicolumn{3}{|l|}{ Rigid } \\
\hline & & $\mathbf{F}$ & \multicolumn{3}{|l|}{ Flexible } \\
\hline \multirow{4}{*}{3} & \multirow{4}{*}{$\begin{array}{l}\text { Soil category } \\
\text { (for rigid pavements }-k, \\
\text { for flexible pavements }-C B R \text { ) }\end{array}$} & $\mathbf{A}$ & $\begin{array}{l}\text { high load } \\
\text { capacity }\end{array}$ & $\mathrm{k}>120 \mathrm{MN} / \mathrm{m}^{3}$ & $\mathrm{CBR}>13$ \\
\hline & & B & $\begin{array}{l}\text { medium load } \\
\text { capacity }\end{array}$ & $60-120 \mathrm{MN} / \mathrm{m}^{3}$ & $8-13$ \\
\hline & & $\mathbf{C}$ & $\begin{array}{l}\text { low load } \\
\text { capacity }\end{array}$ & $25-60 \mathrm{MN} / \mathrm{m}^{3}$ & $4-8$ \\
\hline & & D & $\begin{array}{l}\text { very low load } \\
\text { capacity }\end{array}$ & $\mathrm{k}<25 \mathrm{MN} / \mathrm{m}^{3}$ & $\mathrm{CBR}<4$ \\
\hline \multirow{4}{*}{4} & \multirow{4}{*}{$\begin{array}{l}\text { Allowable pressure in aeroplane } \\
\text { tyres }\end{array}$} & $\mathbf{W}$ & \multicolumn{3}{|c|}{ no limitations } \\
\hline & & $\mathbf{X}$ & \multicolumn{3}{|c|}{ medium up to $1.5 \mathrm{MPa}$} \\
\hline & & $\mathbf{Y}$ & \multicolumn{3}{|c|}{ low up to $1.0 \mathrm{MPa}$} \\
\hline & & $\mathbf{Z}$ & \multicolumn{3}{|c|}{ very low up to $0.5 \mathrm{MPa}$} \\
\hline \multirow{2}{*}{5} & \multirow{2}{*}{ Assessment method } & $\mathbf{T}$ & \multicolumn{3}{|c|}{ technical method } \\
\hline & & $\mathbf{U}$ & \multicolumn{3}{|c|}{ experimental method } \\
\hline
\end{tabular}

Verifying whether a given aeroplane can operate safely at a given airport involves a comparison of the pavement PCN for various airport functional elements and the aeroplane ACN.

\section{Airfield pavement structures}

Many years of experience of the Airport Department of Air Force Institute of Technology (AFIT) in terms of conducted tests of airport surfaces' load capacity on military facilities and Airports confirms that there are three basic types of pavement structures in Poland:

- rigid (resilient) pavements made of cement concrete;

- flexible pavements made of asphalt concrete;

- complex (elastic-flexible) pavements, in which the rigid structure is reinforced with a layer of asphalt concrete.

The proper identification of the structure has a significant impact on determining the airfield pavements' load capacity because the manner of transferring the load by the aircraft to the ground subsoil depends on the type of airfield pavement structure. Depending on the type and the manner of operation, to express the nature of the aircraft's impact on the pavement, appropriate mathematical models, which are presented in the chapter 4 , are applied. 
The basic type of airfield pavement are pavements made of cement concrete. The airfield pavement with rigid structure is a system of several layers stacked on natural or improved subsoil forming a supporting structure that allows travelling of aircraft, as well as taking and transferring loads from them to the ground subsoil. The load bearing layer (surfacing) is made in the form of slabs made of ordinary, dowelled, reinforced, or prestressed cement concrete. Figure 1 below shows a typical structure of a rigid (resilient) airfield pavement [6].

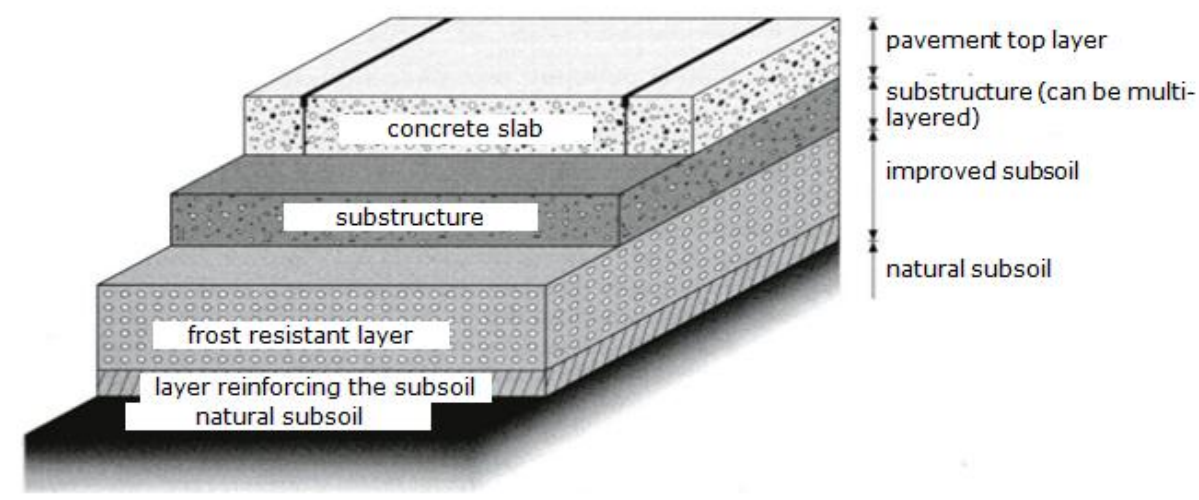

Fig. 1 Layer arrangement in the structure of a cement concrete pavement

\section{Computational models of rigid airfield pavements}

Over the past several dozen years, together with the development of new technologies and computer techniques in the methods of pavement and ground subsoil dimensioning, the constant evolution of models of airfield pavement structures is observed. Models more complex in terms of mathematical notation are more and more often applied in them, which at the same time are closer and closer to the actual behaviour of the structure. In the research practice for rigid pavements, the model of plate of finite dimensions in plane on the Winkler type substrate is applied most often [1].

\section{Computational models of ground subsoil}

The load coming from the aircraft, exerted on the airfield pavement, is transmitted through the substructure to the ground subsoil, which is an integral part of the pavement structure. The operation of ground subsoil is characterised by distribution of stresses and strains. In order to determine the resistance of ground to loads, we use a computational model, which shows the relationship between the load transmitted to the ground and its strain. 
Influence of the condition of the airfield pavement structures on the operation... Wpływ stanu nośności konstrukcji nawierzchni lotniskowych na bezpieczeństwo...

For well over a century, various physical and mathematical models of the ground describing approximately the behaviour of the actual ground base have been created [3]. In 1867, Winkler proposed a model of an elastic substrate, assuming that it is composed of a system of springs that are unconnected to each other on a non-deformable base, as shown in Fig. 2 [3].

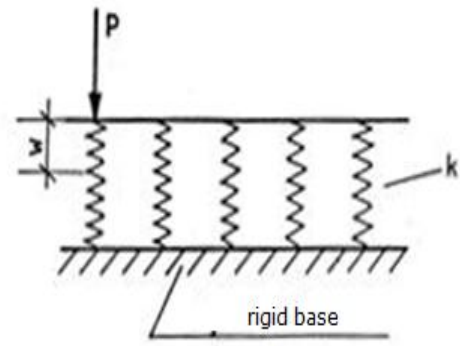

a) b)

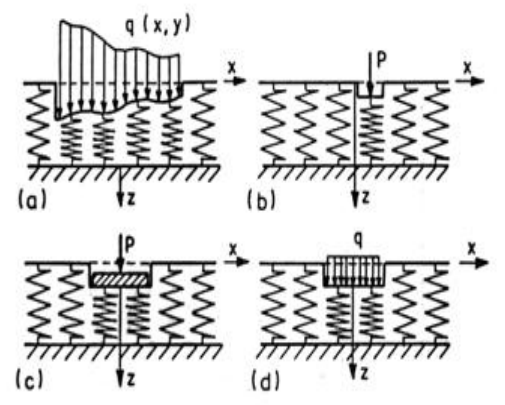

Fig. 2 Model of the Winkler elastic substrate a) substrate model b) substrate deflection

This model is described with the following equation [3]:

where:

$$
p\left(x^{\alpha}\right)=k w\left(x^{\alpha}\right)
$$

$p\left(x^{\alpha}\right)$ - function describing the load exerting on the substrate;

$k \quad$ - substrate reaction coefficient $\left[\mathrm{N} / \mathrm{m}^{3}\right]$;

$w\left(x^{\alpha}\right)$ - function describing the substrate deflection.

Another example is the Kelvin-Voigt model substrate, which is a generalisation of the Winkler model, in which attenuation in the substrate is taken into account assuming a parallel connection of the spring and attenuator's elements. In turn, the Maxwell substrate model is a serial connection of the spring and attenuator. The so-called standard models that are certain combinations of the springs and attenuators are the generalisation of the Kelvin-Voight and Maxwell models.

\section{Computational models of airfield pavements}

In order to assess the mechanical properties of concrete airfield pavements' structures, the computational model based on the theory of elasticity is used in practice. As an example of such a model, a finite or infinite slab in plane resting on the Winkler substrate can be presented (Fig. 3). The problem was developed by: Westergaard, Pickett and Ray, as well as Korenev. 


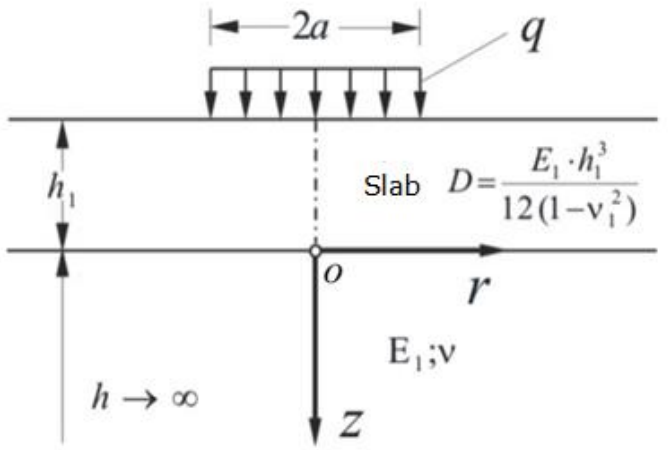

Fig. 3 Pavement model-finite or infinite slab, in plane, resting on the Winkler substrate

The slab is described with the Young's modulus E, the Poisson's coefficient $v$, and thickness $h$. The substrate was, in turn, described with the substrate reaction coefficient $k$. The Westergaard's model, which is the most commonly used in the world airport technique and was presented in detail in paper [2], describes the airfield pavement of the rigid structure that is in the form of plates with finite dimensions in a plane lying on the intertialess Winkler substrate.

\section{Test results}

The assessment of airfield pavement structure's load capacity according to the assumptions of the ACN-PCN method involves measuring elastic deflections of the airport surface using a Heavy Weight Deflectometer $(H W D)$. On the basis of the recorded deflections of the airfield pavement and the results of strength tests of materials taken from the pavement, the moduli of elasticity of particular structural layers are determined and parameters of the ground subsoil are set. Then, the allowable number of loads $N$ is set, which is calculated on the basis of a comparison of the stresses occurring in the concrete airfield pavement for adopted parameters of the computational model, with the allowable stresses designated with a stress criterion taking into account the repeatability of loads. The final result of the analysis is the PCN load capacity index or/and allowable, total number of air operations.

\section{Field tests}

\section{Elastic deflections' measurements}

In order to assess the load capacity of the concrete airfield pavement using the HWD, a measured deflection bowl of the tested structure is used. The result of measuring the pavement are the envelopes of elastic deflections' maximum values measured by all geophones (in the number equal to 9). This set of values is defined as the deflection bowl. 
Influence of the condition of the airfield pavement structures on the operation... Wpływ stanu nośności konstrukcji nawierzchni lotniskowych na bezpieczeństwo...

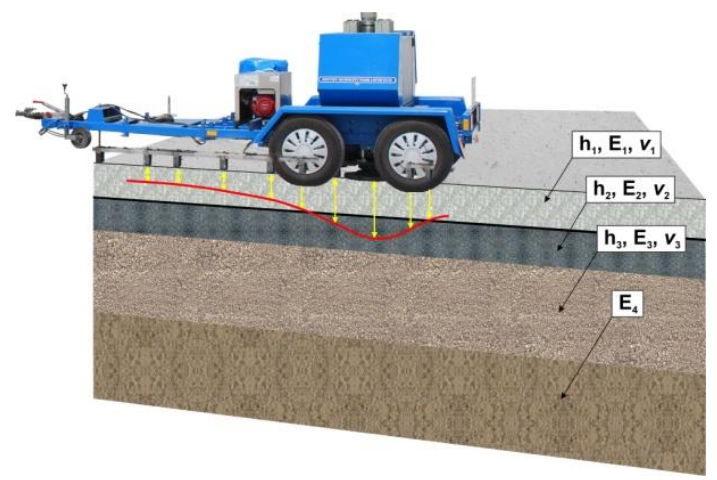

Fig. 4 View of a deflection bowl of measurements with the HWD

The size of deflections in the entire bowl is a dependency, which is described by the following formula:

$$
U_{i}=f(h, E, v)
$$

where:

$U_{i}-$ deflection value of the test surface in the point $i$;

$f$ - functional dependency of components;

$h$ - thickness of the particular pavement's structural layers;

$E-$ modulus of elasticity of the particular structural layers of the pavement and subsoil;

$v \quad$ - Poisson's coefficient of the pavement and subsoil's structural layers.

On the basis of the recorded values of the airfield pavement's deflection, the materials' moduli of elasticity of the particular layers using an iterative comparison of the measured deflections and the theoretical deflections were determined so that the function $F$ has a minimum value. For this purpose, the following dependency is used:

$$
F=\sum_{j=1}^{k}\left(w_{j}-u_{j}\right)^{2}
$$

where:

$F$ - approximation function of actual and theoretical values;

$w_{j}$ - calculated pavement's deflections at a distance $r$ from the centre of a loading plate;

$u_{j} \quad$ - measured pavement deflections at a distance $r$ from the centre of a loading plate;

$k-$ number of geophones (measuring sensors describing the deflection bowl), mostly equal to 9 . 
Figure 5 below shows the example results showing the course of elastic deflections of the tested airfield pavement of a runway, obtained on one of operating airport facilities.

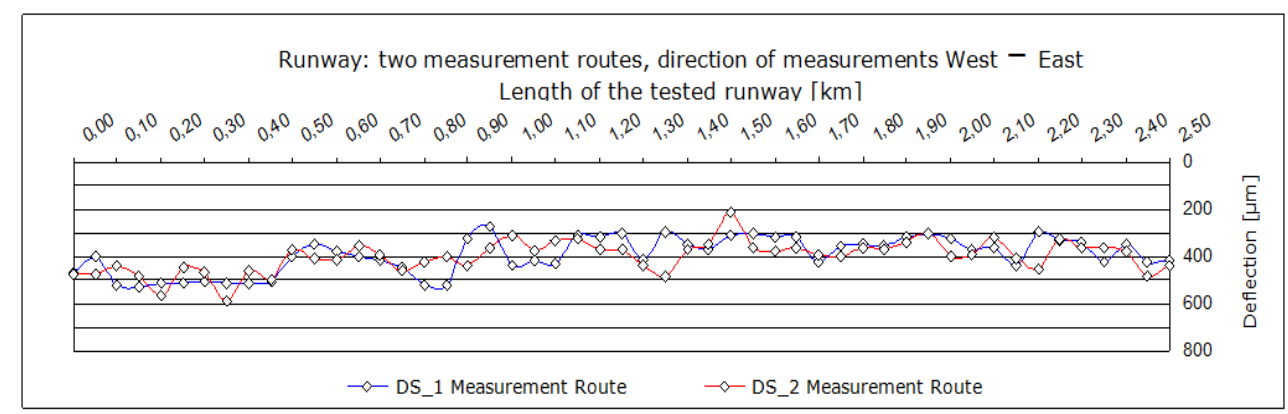

Fig. 5 Course of the elastic deflections of the DS's pavement

\section{Identification of pavement structure}

During the test of the concrete airfield pavement's load capacity, their in situ identification is conducted by measuring the thickness of particular structural layers. The pavement structure is identified on the basis of the standard PN-EN 12504-1:2011 Testing concrete in structures - Part 1: Cored specimens - Taking, examining and testing in compression. For this purpose, samples in the form of cored boreholes with a diameter of $150 \mathrm{~mm}$ are taken from the assessed pavement in the quantity resulting from the provisions of the standard NO-17-A500:2016 Nawierzchnie drogowe $i$ lotniskowe - Badania nośności (Road and airfield pavements - Studies of load capacity).

\section{Identification of ground subsoil}

In order to determine the impact of the aeroplane on the airfield pavement with the ACN, the distribution of the subsoil's load capacity into four categories: high, medium, low, and very low was adopted. Table 2 shows the ranges of the subsoil's load capacity characteristic for these categories, differentiating between the physical quantities describing this parameter according to the type of an airfield pavement. The category of load bearing carrying of the ground subsoil for the rigid pavements is determined on the basis of the ground subsoil reaction coefficient $k$, whereas for flexible pavements - on the basis of the California bearing ratio $C B R$.

Table 2. Ranges of load capacity for the airfield pavements [7]

\begin{tabular}{|l|c|c|}
\hline \multirow{2}{*}{ Subsoil load capacity category } & \multicolumn{2}{|c|}{ Subsoil load capacity range } \\
\cline { 2 - 3 } & $k\left[\mathrm{MN} / \mathrm{m}^{3}\right]$ & $C B R[\%]$ \\
\hline A - high load capacity & $>120$ & $>13$ \\
\hline B - medium load capacity & $60-120$ & $8-13$ \\
\hline C - low load capacity & $25-60$ & $4-8$ \\
\hline D - very low load capacity & $<25$ & $<4$ \\
\hline
\end{tabular}


Influence of the condition of the airfield pavement structures on the operation... Wplyw stanu nośności konstrukcji nawierzchni lotniskowych na bezpieczeństwo...

The category of ground subsoil's load capacity under the assessed structure of the concrete airfield pavement should be determined on the basis of field tests, in accordance with the requirements of the draft defence standard prNO defense-17-A503 Nawierzchnie lotniskowe - Naturalne nawierzchnie lotniskowe - Badania nośności (Airfield pavements - Natural airfield pavements - Studies of load capacity). Table 3 shows the example results (from three test points) of the test of ground subsoil's load capacity under the structure of the tested airfield pavement of a runway, obtained in one of the operating airport facilities.

Table 3. Results of test of load capacity of the ground subsoil under the DS's pavement structure

\begin{tabular}{|c|c|c|c|}
\hline Airport Functional Element (AFE) & Test point no. & Depth & $\begin{array}{c}\text { CBR } \\
{[\%]}\end{array}$ \\
\hline \multirow{3}{*}{ Runway (DS) } & \multirow{2}{*}{1} & from $0.0 \mathrm{~m}$ to $0.15 \mathrm{~m}$ & 29.8 \\
\cline { 3 - 4 } & & from $0.0 \mathrm{~m}$ to $0.85 \mathrm{~m}$ & 36.9 \\
\cline { 2 - 4 } & \multirow{2}{*}{2} & from $0.0 \mathrm{~m}$ to $0.15 \mathrm{~m}$ & 21.8 \\
\cline { 3 - 4 } & \multirow{2}{*}{3} & from $0.0 \mathrm{~m}$ to $0.85 \mathrm{~m}$ & 30.9 \\
\cline { 2 - 4 } & & from $0.0 \mathrm{~m}$ to $0.15 \mathrm{~m}$ & 24.9 \\
\cline { 2 - 4 } & & from $0.0 \mathrm{~m}$ to $0.85 \mathrm{~m}$ & 41.1 \\
\hline
\end{tabular}

\section{Laboratory tests}

The laboratory tests include checking the bending strength, which is determined on the basis of cylindrical samples taken from the pavements, in accordance with NO-17-A500:2016 [7]. Marking of the bending strength must be performed as follows:

- determine the tensile splitting strength of cored boreholes $\varnothing 150 \mathrm{~mm}$, in accordance with PN-EN 12390-6:2011 Testing hardened concrete - Part 6:

Tensile splitting strength of test specimens;

- convert the tensile splitting strength into bending strength according to NO-17-A500:2016.

Table 4 below shows the example results (from three test points) of the test of ground subsoil's load capacity under the structure of the tested airfield pavement of a runway, obtained in one of the operating airport facilities.

Table 4. Results of test of load capacity of the ground subsoil under the DS's pavement structure

\begin{tabular}{|c|c|c|c|c|c|}
\hline AFE & $\begin{array}{c}\text { Borehole } \\
\text { no. }\end{array}$ & $\begin{array}{c}\text { Layer } \\
\text { no. }\end{array}$ & $\begin{array}{c}\text { Type of } \\
\text { sample } \\
\text { material }\end{array}$ & $\begin{array}{c}\text { Tensile splitting } \\
\text { strength } \\
{[\mathrm{MPa}]}\end{array}$ & $\begin{array}{c}\text { Bending tensile } \\
\text { strength } \\
{[\mathrm{MPa}]}\end{array}$ \\
\hline \multirow{2}{*}{ DS } & 1 & 1 & BC & 3.7 & 5.6 \\
\cline { 2 - 6 } & 2 & 1 & BC & 3.8 & 5.7 \\
\cline { 2 - 6 } & 3 & 1 & BC & 4.0 & 6.0 \\
\hline
\end{tabular}




\section{Results of load capacity}

Load capacity of the airfield pavements can be expressed with the PCN index or the allowable air operations number. In both cases, the number of allowable load repetitions number $\mathrm{N}$, which impacts directly the load capacity value, is important. Attention must be paid to the fact that the allowable load repetitions number $\mathrm{N}$ is a limited number. The allowable load repetitions number is calculated depending on the adopted computational model of the assessed airfield pavement structure. For the rigid pavements, made of cement concrete, the following formula resulting from the allowable bending stresses criterion is applied [1]:

$$
N=\left[\frac{f_{z g}}{\sigma} \times\left(\frac{E}{30000}\right)^{1.3}\right]^{(1 / 0.233)} \times 10^{4}
$$

where:

$N$ - allowable load repetitions number;

$f_{z g}-$ concrete bending strength [MPa];

$\sigma \quad-$ bending tensile stresses in the lower part of a concrete slab [MPa];

$E \quad-$ modulus of concrete elasticity [MPa].

Table 5 below shows the example final results of the conducted test of load capacity of the tested airfield pavement of a runway of the one of the operating airport facilities.

Table 5. Results of the test of load capacity of a runway's airfield pavement

\begin{tabular}{|c|c|c|}
\hline AFE & $\begin{array}{c}\text { PCN load capacity } \\
\text { index }\end{array}$ & $\begin{array}{c}\text { Total number of } \\
\text { air operations }\end{array}$ \\
\hline DS & $57 / R / A / W / T$ & 19,000 \\
\hline
\end{tabular}

\section{Conclusion}

The safety of executing air operation by the aircraft depends directly on the load capacity condition of the airfield pavement structures. The method of assessing the airfield pavement structures' load capacity (ACN-PCN) is a non-destructive method that enables to classify the pavements' load capacity on the basis on the rheological test results of the layers' material and, at the same time, precise predicting the pavements operating time with known predictions of the land traffic of the aircraft.

However, the comprehensive analysis of the load capacity's condition of the airfield pavement structures is very complex, since its final result depends not only on the aircraft loads, but also on other external factors (weather conditions, number 
Influence of the condition of the airfield pavement structures on the operation... Wpływ stanu nośności konstrukcji nawierzchni lotniskowych na bezpieczeństwo...

of air operations, concrete's bending tensile strength, pavement's structural crosssection, condition of the ground subsoil's load capacity).

The essential problem when dimensioning the airfield pavements is the adoption of an appropriate computational model of the structure, which will behave in a manner consistent with the behaviour of actual layers of an analysed arrangement when loaded. In order to express the nature of the aircraft's impact on a rigid (elastic) surface, the computational model of a plate of finite dimensions in plan on the Winkler substrate, which was developed by Westergard, is applied. The paper presented the example results of load capacity tests performed on one of the airport facilities operated in Poland.

\section{References}

[1] Blacha K., Wesołowski M.: Zależność wskaźnika nośności PCN od liczby operacji lotniczych przy określaniu nośności konstrukcji nawierzchni lotniskowych metodą ACN-PCN [Dependency of the load capacity PCN index and the allowable air operations number when determining the airfield pavements load capacity with the ACN-PCN method], Logistyka nr [Logistics no.] 6/2014.

[2] Blacha K., Wesołowski M.: Analysis of the load capacity of rigid airfield pavements according to the ACN-PCN method's assumptions, Logistyka nr [Logistics no.] 6/2015.

[3] Jemielita G., Szcześniak W.: Sposoby modelowania podłoża [Manners of modelling the substrate], Work supported with research examples, Instytut Mechaniki Konstrukcji Inżynierskich [Mechanical Engineering of Civil Engineering Stuctures Institute].

[4] Nita P.: Budowa i utrzymanie nawierzchni lotniskowych. [Construction and maintenance of airfield pavements], WKŁ, Warszawa 1999, 2008.

[5] Nita P.: Betonowe nawierzchnie lotniskowe. Teoria i wymiarowanie konstrukcyjne [Concrete airfield pavements. Theory and structural dimensioning], Wydawnictwo Instytutu Technicznego Wojsk Lotniczych, Warszawa, 2005.

[6] Szydło A.: Nawierzchnie drogowe $\mathrm{z}$ betonu cementowego. Teoria, Wymiarowanie, Realizacja. [Cement concrete road pavements. Theory, Dimensioning, Execution]. Polski Cement Sp. z o.o., Kraków 2004.

[7] Wesołowski M.: Nośność mobilnych pokryć kompozytowych stosowanych do odbudowy nawierzchni lotniskowych, [Load capacity of mobile composite covers used to reconstruct airfield pavements], Doctoral thesis, MUT, Warszawa 2012.

[8] ICAO, Aerodrome Design Manual, Part 3, Pavements, 1983. 
[9] NO-17-A500:2016 Nawierzchnie drogowe i lotniskowe - Badania nośności [Road and airfield pavements - Studies of load capacity].

[10] prNO-17-A503 Nawierzchnie lotniskowe - Naturalne nawierzchnie lotniskowe - Badania nośności [Airfield pavements - Natural airfield pavements - Studies of load capacity].

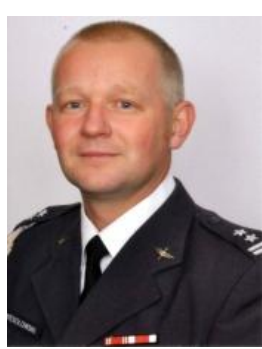

Lt. Col. Mariusz Wesotowski, Ph.D. Eng., a graduate of the Military University of Technology and the Warsaw University of Technology. Head of the Airport Department of Air Force Institute of Technology. His specialisation is design, construction, and assessment of the technical condition of the airfield pavement structures (Share 35\%).

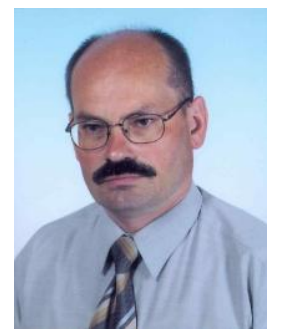

Piotr Barszcz, Ph.D. Eng., a graduate of the Military University of Technology. An assistant professor in the Airport Department in Air Force Institute of Technology. His specialisation is the issue of corrosion, reliability, safety, and operation of aircraft. He participates in the works aimed at the development and implementation of the system of airfield pavement management (Share 30\%).

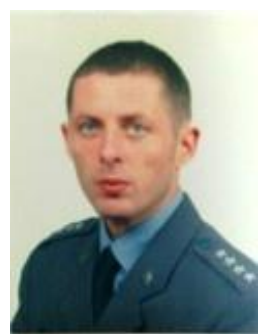

Capt. Krzysztof Blacha, MSc Eng., a graduate of the Faculty of Military Engineering of the Military Academy of Land Forces and of the Faculty of Civil Engineering and Geodesy of the Military University of Technology. An assistant in the Airport Department in Air Force Institute of Technology. His specialisation is design, construction and assessment of the technical condition of the airfield pavement structures (Share 35\%). 
Influence of the condition of the airfield pavement structures on the operation...

Wpływ stanu nośności konstrukcji nawierzchni lotniskowych na bezpieczeństwo...

\section{WPLYW STANU NOŚNOŚCI KONSTRUKCJI NAWIERZCHNI LOTNISKOWYCH NA BEZPIECZEŃSTWO OPERACJI LOTNICZYCH STATKÓW POWIETRZNYCH}

\section{Wstęp}

Nawierzchnia lotniskowa to wyznaczona i odpowiednio przygotowana powierzchnia elementu funkcjonalnego lotniska (EFL) spełniającego określoną funkcję w realizacji operacji lotniczych, tj. przeznaczonego do ruchu, postoju i obsługi statków powietrznych. Konstrukcję nawierzchni lotniskowej stanowi najczęściej zespół warstw, których zadaniem jest przejęcie i przeniesienie na podłoże gruntowe obciążeń pochodzących od poruszających się statków powietrznych i śmigłowców w sposób zapewniający określoną jej trwałość.

Nawierzchnie lotniskowe można podzielić na dwie grupy [5]:

- nawierzchnie naturalne: gruntowe, trawiaste i darniowe,

- nawierzchnie sztuczne.

Jedną z głównych cech eksploatacyjnych nawierzchni lotniskowej jest jej nośność rozumiana, jako zdolność układu konstrukcyjnego do przenoszenia obciążeń od statków powietrznych $\mathrm{W}$ określonym czasie. Zgodnie $\mathrm{z}$ obowiązującymi wymaganiami określonymi przez Organizację Międzynarodowego Lotnictwa Cywilnego (International Civil Aviation Organization - ICAO), nośność konstrukcji nawierzchni lotniskowych określa się metodą ACN-PCN [8]. Nośność nawierzchni uzależniona jest nie tylko od obciążeń samolotów, lecz także od wielu czynników zewnętrznych, w tym m.in. od czynników atmosferycznych [4], do których można zaliczyć:

- liczbę operacji lotniczych (obciążeń statków powietrznych) odbywających się lub planowanych na przedmiotowej nawierzchni,

- przekrój konstrukcji nawierzchni - grubość poszczególnych warstw konstrukcyjnych,

- wytrzymałość betonu na zginanie,

- moduł sprężystości betonu,

- współczynnik Poissona warstw konstrukcyjnych nawierzchni lotniskowej i podłoża gruntowego,

- rodzaj, zagęszczenie i wilgotność podłoża gruntowego,

- nośność podłoża gruntowego,

- temperaturę podczas prowadzonych badań terenowych.

Do pełnej analizy nośności nawierzchni lotniskowej niezbędna jest identyfikacja parametrów fizykomechanicznych materiałów poszczególnych jej warstw konstrukcyjnych i podłoża gruntowego. Identyfikacja powinna być prowadzona w sposób uwzględniający rzeczywiste warunki pracy nawierzchni, ponieważ ma istotny wpływ na określanie nośności nawierzchni lotniskowych ze względu na fakt, iż sposób przekazywania obciążenia przez statki powietrzne na podłoże gruntowe jest zależny od rodzaju konstrukcji nawierzchni lotniskowej. 
W zależności od jej rodzaju oraz sposobu pracy, do wyrażenia charakteru oddziaływania statku powietrznego na nawierzchnię wykorzystuje się odpowiednie modele matematyczne.

\section{Założenia metody ACN-PCN}

Ocena nośności konstrukcji nawierzchni lotniskowych aktualnie przeprowadzana jest metodą ACN-PCN, w której liczba klasyfikacyjna samolotu ACN (Aircraft Classification Number) wyraża względne oddziaływanie statku powietrznego na nawierzchnię lotniskową, gdy jest ustalona standardowa nośność podłoża gruntowego. ICAO określiła procedurę wyznaczania liczby ACN, która zakłada, że standardowymi wielkościami w procesie jej obliczania są:

- ciśnienie w oponie pojedynczego koła goleni głównej równe 1,25 MPa,

- dopuszczalne naprężenia zginające w płycie betonowej (dla nawierzchni sztywnych) równe $2,75 \mathrm{MPa}$,

- dopuszczalna liczba obciążeń w przypadku nawierzchni podatnych,

- nośność podłoża gruntowego opisywana w odniesieniu do nawierzchni sztywnych współczynnikiem reakcji podłoża $k$, zaś dla nawierzchni podatnych wskaźnikiem CBR.

Liczbę ACN określa się wzorem:

$$
A C N=2 \cdot P_{r}
$$

gdzie:

$P_{r}$ - obciążenie równoważne $\mathrm{w}$ tysiącach kilogramów o takiej wartości, że niezbędna do jego przeniesienia grubość nawierzchni jest równa grubości wyznaczonej jak dla rzeczywistego obciążenia: $P_{r}=\pi \cdot q \cdot a^{2}$,

$q$ - równomierne obciążenie o intensywności $1,25 \mathrm{MPa}$, rozłożone na powierzchni kołowej o promieniu $a$.

Na nośność konstrukcji nawierzchni sztywnej mają wpływ: kształt i wymiary płyt betonowych, sposób ich przylegania do podłoża gruntowego oraz parametry wytrzymałościowe betonu. Nośność konstrukcji nawierzchni podatnej zależy od liczby i grubości warstw oraz właściwości fizykomechanicznych materiałów tych warstw. Szczególnie istotny wpływ mają moduły sztywności poszczególnych warstw konstrukcyjnych, odpowiadające im wartości współczynnika Poissona oraz stan połączeń międzywarstwowych, spękania $\mathrm{w}$ warstwach nawierzchni, woda infiltrująca $\mathrm{w}$ konstrukcję $\mathrm{i}$ podłoże gruntowe, a także temperatura warstw asfaltowych. Ważnym czynnikiem decydującym o zdolności nawierzchni do przejmowania obciążeń jest nośność podłoża gruntowego. Liczby ACN samolotu wyznacza się $\mathrm{z}$ uwzględnieniem standardowych wartości nośności podłoża gruntowego. Dla każdego statku powietrznego liczba ACN jest zbiorem liczb zależnych od rodzaju konstrukcji nawierzchni lotniskowej (sztywna i podatna) oraz nośności podłoża gruntowego. Liczba klasyfikacyjna nawierzchni PCN (Pavement Classification Number) wyraża nośność nawierzchni lotniskowej dla ograniczonej liczby przejazdów statków powietrznych o liczbie $\mathrm{ACN}=\mathrm{PCN}$. 
Influence of the condition of the airfield pavement structures on the operation... Wptyw stanu nośności konstrukcji nawierzchni lotniskowych na bezpieczeństwo...

Jest ona równoważna 1/500 dopuszczalnego obciążenia (wyrażonego $\mathrm{w}$ kilogramach masy) przyłożonego do nawierzchni za pośrednictwem pojedynczego koła ze standardowym ciśnieniem równym 1,25 $\mathrm{MPa}$.

Zgodnie z przyjętymi ustaleniami, w metodzie ACN-PCN nośność nawierzchni lotniskowej opisana jest przez grupę symboli przedstawiającą poszczególne parametry konstrukcji oraz informującą o metodzie wyznaczania liczby PCN, np. PCN 48/R/B/X/T. Szczegółowy sposób interpretacji ww. zapisu przedstawiono w tabeli 1.

Tabela 1.Sposób interpretacji zapisu wskaźnika PCN

\begin{tabular}{|c|c|c|c|c|c|}
\hline 1 & Bezwymiarowa liczba PCN & & & & \\
\hline \multirow{2}{*}{2} & \multirow{2}{*}{ Rodzaj nawierzchni } & $\mathbf{R}$ & \multicolumn{3}{|l|}{ Sztywna } \\
\hline & & $\mathbf{F}$ & \multicolumn{3}{|l|}{ Podatna } \\
\hline \multirow{4}{*}{3} & \multirow{4}{*}{$\begin{array}{l}\text { Kategoria gruntu } \\
\text { (dla nawierzchni sztywnych }-k, \\
\text { dla nawierzchni podatnych }-C B R \text { ) }\end{array}$} & $\mathbf{A}$ & duża nośność & $\mathrm{k}>120 \mathrm{MN} / \mathrm{m}^{3}$ & $\mathrm{CBR}>13$ \\
\hline & & B & średnia nośność & $60-120 \mathrm{MN} / \mathrm{m}^{3}$ & $8-13$ \\
\hline & & $\mathbf{C}$ & niska nośność & $25-60 \mathrm{MN} / \mathrm{m}^{3}$ & $4-8$ \\
\hline & & $\mathbf{D}$ & $\begin{array}{l}\text { bardzo niska } \\
\text { nośność }\end{array}$ & $\mathrm{k}<25 \mathrm{MN} / \mathrm{m}^{3}$ & $\mathrm{CBR}<4$ \\
\hline \multirow{4}{*}{4} & \multirow{4}{*}{$\begin{array}{l}\text { Dopuszczalne ciśnienie w oponach } \\
\text { samolotu }\end{array}$} & $\mathbf{W}$ & \multicolumn{3}{|l|}{ bez ograniczeń } \\
\hline & & $\mathbf{X}$ & \multicolumn{3}{|c|}{ średnie do 1,5 MPa } \\
\hline & & $\mathbf{Y}$ & \multicolumn{3}{|c|}{ niskie do 1,0 MPa } \\
\hline & & $\mathbf{Z}$ & \multicolumn{3}{|c|}{ bardzo niskie do $0,5 \mathrm{MPa}$} \\
\hline \multirow{2}{*}{5} & \multirow{2}{*}{ Metoda oceny } & $\mathbf{T}$ & \multicolumn{3}{|c|}{ metoda techniczna } \\
\hline & & $\mathbf{U}$ & \multicolumn{3}{|c|}{ metoda doświadczalna } \\
\hline
\end{tabular}

Sprawdzenie, czy dany samolot może bezpiecznie operować na danym lotnisku polega na porównaniu liczby PCN nawierzchni dla poszczególnych elementów funkcjonalnych lotniska oraz liczby ACN samolotu.

\section{Układy konstrukcyjne nawierzchni lotniskowych}

Wieloletnie doświadczenia Zakładu Lotniskowego Instytutu Technicznego Wojsk Lotniczych (ITWL) w zakresie prowadzonych badań nośności nawierzchni lotniskowych na obiektach wojskowych oraz w Portach Lotniczych potwierdzają, że w Polsce można wyróżnić trzy podstawowe typy konstrukcji nawierzchni:

- nawierzchnie sztywne (sprężyste) wykonane $\mathrm{z}$ betonu cementowego,

- nawierzchnie podatne wykonane $\mathrm{z}$ betonu asfaltowego,

- nawierzchnie złożone (sprężysto - podatne), w których konstrukcja sztywna jest wzmocniona warstwą z betonu asfaltowego.

Prawidłowa identyfikacja konstrukcji ma istotny wpływ na określanie nośności nawierzchni lotniskowych ze względu na fakt, iż sposób przekazywania obciążenia przez statki powietrzne na podłoże gruntowe jest zależny od rodzaju konstrukcji nawierzchni lotniskowej. W zależności od jej rodzaju oraz sposobu pracy, do wyrażenia charakteru oddziaływania statku powietrznego na nawierzchnię wykorzystuje się odpowiednie modele matematyczne, które zostały przedstawione w rozdziale 4.

Podstawowym rodzajem nawierzchni lotniskowych są nawierzchnie $\mathrm{z}$ betonu cementowego. Nawierzchnia lotniskowa o układzie sztywnym to układ kilku 
warstw ułożonych na naturalnym lub ulepszonym podłożu, tworzących konstrukcję nośną umożliwiającą ruch statków powietrznych oraz przejmowanie i przenoszenie na podłoże gruntowe pochodzących od nich obciążeń. Warstwa nośna (warstwa jezdna) wykonana jest $\mathrm{w}$ postaci płyt $\mathrm{z}$ betonu cementowego zwykłego, dyblowanego, zbrojonego lub sprężonego. Poniżej, na rys 1. przedstawiono typowy układ konstrukcyjny sztywnej (sprężystej) nawierzchni lotniskowych [6].

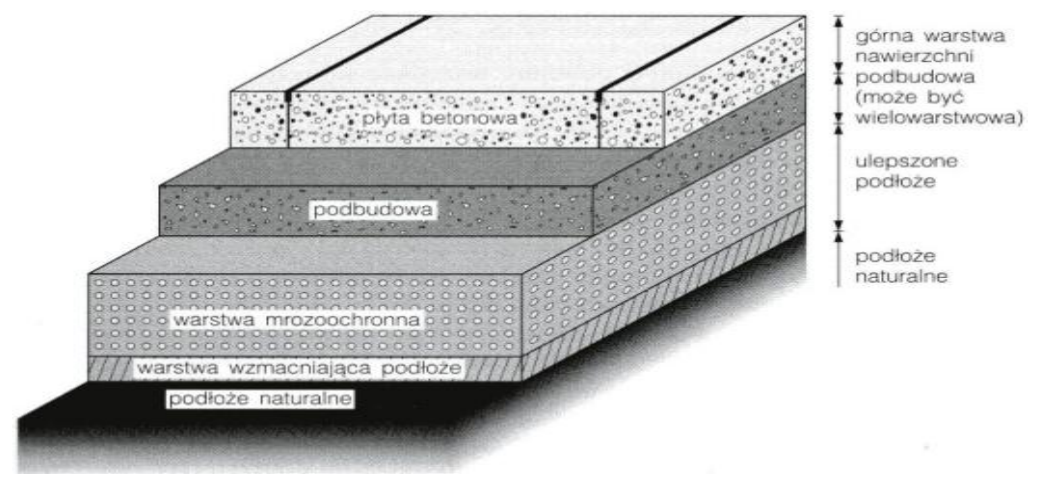

Rys. 1 Układ warstw w konstrukcji nawierzchni z betonu cementowego

\section{Modele obliczeniowe sztywnych nawierzchni lotniskowych}

$\mathrm{Na}$ przestrzeni ostatnich kilkudziesięciu lat wraz z rozwojem nowych technologii i technik komputerowych $\mathrm{w}$ metodach wymiarowania nawierzchni i podłoża gruntowego obserwuje się stałą ewolucję modeli konstrukcji nawierzchni lotniskowych. Znajdują w nich zastosowanie coraz częściej modele bardziej skomplikowane pod względem zapisu matematycznego, które jednocześnie coraz bardziej zbliżone są do rzeczywistego zachowania się konstrukcji. W praktyce badawczej dla nawierzchni sztywnych najczęściej stosuje się model płyt o skończonych wymiarach w planie położonych na podłożu typu Winklera [1].

\section{Modele obliczeniowe podłoża gruntowego}

Obciążenie pochodzące od statku powietrznego, wywierane na nawierzchnię lotniskową, przekazywane jest poprzez podbudowę na podłoże gruntowe, stanowiące integralną część konstrukcji nawierzchni. Praca podłoża gruntowego charakteryzowana jest rozkładem naprężeń i odkształceń. W celu określenia wytrzymałości gruntu na obciążenia posługujemy się modelem obliczeniowym, który przedstawia zależność pomiędzy obciążeniem przekazywanym na grunt i jego odkształceniem.

Już od ponad wieku są tworzone różne fizyczne i matematyczne modele podłoża, opisującego $\mathrm{W}$ sposób przybliżony zachowanie się rzeczywistego ośrodka gruntowego [3].

W 1867 roku Winkler zaproponował model podłoża sprężystego zakładając, że składa się ono z układu niepołączonych ze sobą sprężyn na nieodkształcalnej bazie, co przedstawia rys. 2 [3]. 
Influence of the condition of the airfield pavement structures on the operation... Wpływ stanu nośności konstrukcji nawierzchni lotniskowych na bezpieczeństwo...

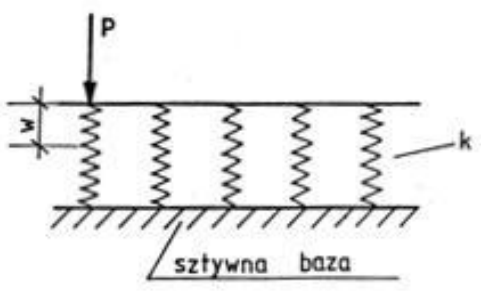

a)

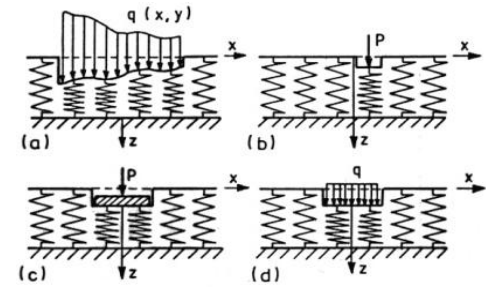

b)

Rys. 2 Model podtoża sprężystego Winklera a) model podtoża b) ugięcie podtoża

Model ten jest opisany poniższym równaniem [3]:

$$
p\left(x^{\alpha}\right)=k w\left(x^{\alpha}\right)
$$

gdzie:

$p\left(x^{\alpha}\right) \quad$ - funkcja opisująca obciążenie działające na podłoże,

$k \quad$ - współczynnik reakcji podłoża $\left[\mathrm{N} / \mathrm{m}^{3}\right]$,

$w\left(x^{\alpha}\right) \quad$ - funkcja opisująca ugięcie podłoża.

Kolejnym przykładem jest model podłoża Kelvina - Voigta, będący uogólnieniem modelu Winklera, w którym uwzględnia się thumienie w podłożu przy założeniu równoległego połączenia elementów sprężyny i tłumika. Z kolei model podłoża Maxwella stanowi szeregowe połączenie sprężyny i tłumika. Uogólnieniem modeli Kelvina - Voigta i Maxwella są tzw. modele standardowe będące pewnymi kombinacjami sprężyn i thumików.

\section{Modele obliczeniowe nawierzchni lotniskowych}

Do oceny mechanicznych własności konstrukcji betonowych nawierzchni lotniskowych, w praktyce wykorzystuje się model obliczeniowy oparty o teorię sprężystości. Jako przykład takiego modelu, można przedstawić płytę ograniczoną lub nieograniczoną w planie, spoczywającą na podłożu Winklera (rys. 3). Problem opracowany przez: Westergaard'a, Pickett'a i Ray'a oraz Koreniewa.

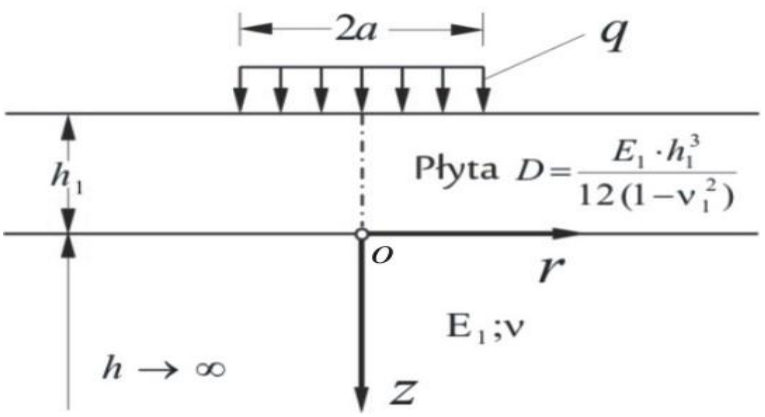

Rys. 3 Model nawierzchni - plyta ograniczona lub nieograniczona w planie, spoczywajaca na podtożu Winklera 
Płyta jest opisana modułem sprężystości Younga $E$, współczynnikiem Poissona $v$ oraz grubością $h$, podłoże zaś współczynnikiem reakcji podłoża $k$. Nawierzchnię lotniskową o konstrukcji sztywnej, czyli w postaci płyt o skończonych wymiarach w planie położonych na bezinercyjnym podłożu typu Winklera, opisuje najczęściej wykorzystywany w światowej technice lotniskowej model Westergaarda, który szczegółowo został przedstawiony w pracy [2].

\section{Wyniki badań}

Ocena nośności konstrukcji nawierzchni lotniskowych według założeń metody ACN-PCN polega na pomiarze ugięć sprężystych nawierzchni lotniskowej przy wykorzystaniu ciężkiego ugięciomierza udarowego typu HWD (Heavy Weight Deflectometer). Na podstawie zarejestrowanych ugięć nawierzchni lotniskowej oraz $\mathrm{w}$ oparciu o wyniki badań wytrzymałościowych materiałów pobranych z nawierzchni, określa się moduły sprężystości poszczególnych warstw konstrukcyjnych i wyznacza się parametry podłoża gruntowego. Następnie wyznaczana jest dopuszczalna liczba obciążeń $N$, którą oblicza się na podstawie porównania naprężeń występujących $\mathrm{w}$ betonowej nawierzchni lotniskowej dla przyjętych parametrów modelu obliczeniowego, z naprężeniami dopuszczalnymi, wyznaczonymi z kryterium naprężeń uwzględniającego powtarzalność obciążeń. Wynikiem końcowym analizy jest wskaźnik nośności PCN lub/i dopuszczalna, całkowita liczba operacji lotniczych.

\section{Badania terenowe}

\section{Pomiary ugięć sprężystych}

Do oceny nośności betonowej nawierzchni lotniskowej za pomocą ugięciomierza udarowego typu HWD, wykorzystuje się zmierzoną czaszę ugięcia badanej konstrukcji. Wynikiem pomiarów nawierzchni są obwiednie maksymalnych wartości ugięć sprężystych zmierzonych przez wszystkie geofony (w liczbie równej 9). Ten zbiór wartości jest definiowany jako czasza ugięcia.

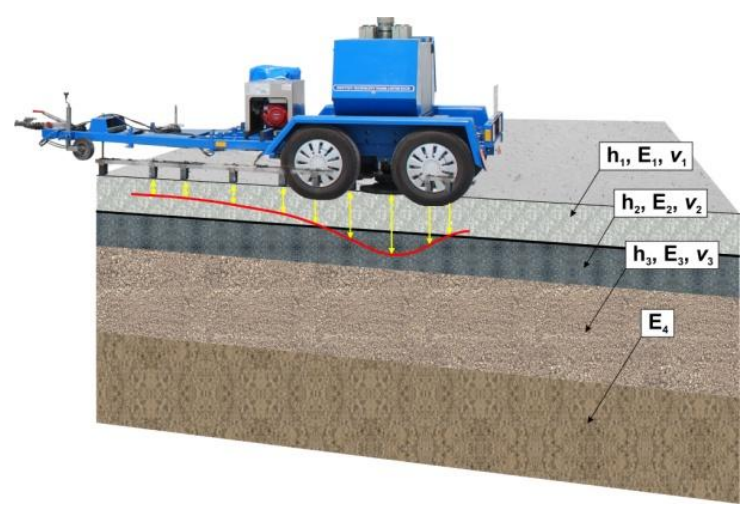

Rys. 4 Widok czaszy ugięcia z pomiarów urządzeniem HWD 
Influence of the condition of the airfield pavement structures on the operation... Wptyw stanu nośności konstrukcji nawierzchni lotniskowych na bezpieczeństwo...

Wielkość ugięć w całej czaszy jest zależnością, którą opisuje poniższy wzór:

$$
U_{i}=f(h, E, v)
$$

gdzie:

$U_{i}$ - wartość ugięcia badanej powierzchni w punkcie $i$,

$f$ - zależność funkcyjna czynników składowych,

$h$ - grubość poszczególnych warstw konstrukcyjnych nawierzchni,

E - moduł sprężystości poszczególnych warstw konstrukcyjnych nawierzchni i podłoża,

$v$ - współczynnik Poissona warstw konstrukcyjnych nawierzchni i podłoża.

Na podstawie zarejestrowanych wartości ugięć nawierzchni lotniskowej wyznacza się moduły sprężystości materiałów poszczególnych warstw za pomocą iteracyjnego porównywania zmierzonych ugięć oraz ugięć teoretycznych tak, aby funkcja $F$ miała wartość minimalną. W tym celu wykorzystuje się zależność:

$$
F=\sum_{j=1}^{k}\left(w_{j}-u_{j}\right)^{2}
$$

gdzie:

$F$ - funkcja przybliżenia wartości rzeczywistych i teoretycznych,

$w_{j}$ - obliczone ugięcia nawierzchni w odległości $r$ od środka płyty obciążającej,

$u_{j}$ - pomierzone ugięcia nawierzchni w odległości $r$ od środka płyty obciążającej,

$k$ - liczba geofonów (czujników pomiarowych opisujących czaszę ugięć) równa najczęściej 9.

Poniżej, na rys. 5 zaprezentowano przykładowe wyniki przedstawiające przebieg ugięć sprężystych badanej nawierzchni lotniskowej drogi startowej, uzyskane na jednym z obiektów lotniskowych będących w eksploatacji.

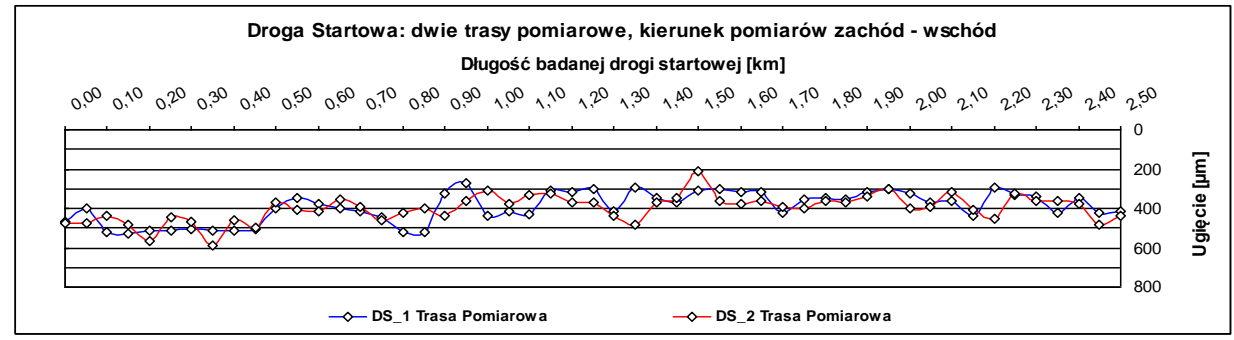

Rys. 5 Przebieg ugięć sprężystych nawierzchni DS

\section{Identyfikacja konstrukcji nawierzchni}

W czasie badania nośności betonowych nawierzchni lotniskowych dokonuje się ich identyfikacji in situ poprzez pomiar grubości poszczególnych warstw konstrukcyjnych. Identyfikację układu konstrukcyjnego nawierzchni przeprowadza się na podstawie normy PN-EN 12504-1:2011 Badania betonu w konstrukcjachCzęść 1: Próbki rdzeniowe - Pobieranie, ocena $i$ badanie wytrzymałości na ściskanie. W tym celu $\mathrm{z}$ ocenianej nawierzchni pobiera się próbki $\mathrm{w}$ postaci odwiertów rdzeniowych o średnicy $150 \mathrm{~mm}$, w ilości wynikającej z postanowień normy NO-17-A500:2016 Nawierzchnie lotniskowe i drogowe - Badania nośności. 


\section{Identyfikacja podtoża gruntowego}

W celu określenia oddziaływania samolotu na nawierzchnię lotniskową poprzez liczbę klasyfikacyjną samolotu ACN przyjęto podział nośności podłoża na cztery kategorie: wysoką, średnią, niską i bardzo niską. W tabeli 2 przedstawiono zakresy nośności podłoża charakterystyczne dla tych kategorii, różnicując wielkości fizyczne opisujące ten parametr ze względu na rodzaj nawierzchni lotniskowej. Kategorię nośności podłoża gruntowego dla nawierzchni sztywnych określa się na podstawie współczynnika reakcji podłoża gruntowego $k$, natomiast dla nawierzchni podatnych na podstawie kalifornijskiego wskaźnika nośności $C B R$.

Tabela 2. Zakresy nośności podtoża dla nawierzchni lotniskowych [7]

\begin{tabular}{|l|c|c|}
\hline \multirow{2}{*}{ Kategoria nośności podłoża } & \multicolumn{2}{|c|}{ Zakres nośności podłoża } \\
\cline { 2 - 3 } & $k\left[\mathrm{MN} / \mathrm{m}^{3}\right]$ & $C B R[\%]$ \\
\hline $\mathrm{A}-$ wysoka nośność & $>120$ & $>13$ \\
\hline $\mathrm{B}-$ średnia nośność & $60-120$ & $8-13$ \\
\hline $\mathrm{C}-$ niska nośność & $25-60$ & $4-8$ \\
\hline $\mathrm{D}-$ bardzo niska nośność & $<25$ & $<4$ \\
\hline
\end{tabular}

Kategorię nośności podłoża gruntowego pod ocenianą konstrukcją betonowej nawierzchni lotniskowej należy określać na podstawie badań polowych, zgodnie z wymaganiami projektu normy obronnej prNO-17-A503 Nawierzchnie lotniskowe - Naturalne nawierzchnie lotniskowe - Badania nośności.

Poniżej, w tabeli 3 przedstawiono przykładowe wyniki (z trzech punktów badawczych) badania nośności podłoża gruntowego pod konstrukcją badanej nawierzchni lotniskowej drogi startowej, uzyskane na jednym $\mathrm{z}$ obiektów lotniskowych będących w eksploatacji.

Tabela 3. Wyniki badań nośności podtoża gruntowego pod konstrukcja nawierzchni DS

\begin{tabular}{|c|c|c|c|}
\hline $\begin{array}{l}\text { Element Funkcjonalny Lotniska } \\
\text { (EFL) }\end{array}$ & Nr punktu badawczego & Głębokość & $\begin{array}{c}\text { CBR } \\
{[\%]} \\
\end{array}$ \\
\hline \multirow{6}{*}{ Droga Startowa (DS) } & \multirow{2}{*}{1} & od $0,0 \mathrm{~m}$ do $0,15 \mathrm{~m}$ & 29,8 \\
\hline & & od $0,0 \mathrm{~m}$ do $0,85 \mathrm{~m}$ & 36,9 \\
\hline & \multirow{2}{*}{2} & od $0,0 \mathrm{~m}$ do $0,15 \mathrm{~m}$ & 21,8 \\
\hline & & od $0,0 \mathrm{~m}$ do $0,85 \mathrm{~m}$ & 30,9 \\
\hline & \multirow{2}{*}{3} & od $0,0 \mathrm{~m}$ do $0,15 \mathrm{~m}$ & 24,9 \\
\hline & & od $0,0 \mathrm{~m}$ do $0,85 \mathrm{~m}$ & 41,1 \\
\hline
\end{tabular}

\section{Badania laboratoryjne}

Badania laboratoryjne obejmują sprawdzenie wytrzymałości na zginanie, którą określa się na podstawie próbek walcowych pobranych z nawierzchni, zgodnie z NO-17-A500:2016 [7].Oznaczenie wytrzymałości na zginanie należy wykonać w następujący sposób:

- określić wytrzymałość na rozciąganie przy rozłupywaniu odwiertów rdzeniowych $\varnothing 150$ mm, zgodnie z PN-EN 12390-6:2011 Badania betonu Czesść 6: Wytrzymałość na rozciaganie przy rozłupywaniu próbek do badań, 
Influence of the condition of the airfield pavement structures on the operation... Wpływ stanu nośności konstrukcji nawierzchni lotniskowych na bezpieczeństwo...

- wytrzymałość na rozciąganie przy rozłupywaniu betonu cementowego przeliczyć na wytrzymałość na zginanie zgodnie z normą NO-17-A500:2016.

Poniżej, w tabeli 4 przedstawiono przykładowe wyniki (z trzech punktów badawczych) badania nośności podłoża gruntowego pod konstrukcją badanej nawierzchni lotniskowej drogi startowej, uzyskane na jednym $\mathrm{z}$ obiektów lotniskowych będących w eksploatacji.

Tabela 4. Wyniki badań nośności podłoża gruntowego pod konstrukcja nawierzchni DS

\begin{tabular}{|c|c|c|c|c|c|}
\hline \multirow{2}{*}{ ELF } & $\begin{array}{c}\mathrm{Nr} \\
\text { odwiertu }\end{array}$ & $\begin{array}{c}\mathrm{Nr} \\
\text { warstwy }\end{array}$ & $\begin{array}{c}\text { Rodzaj } \\
\text { materiału } \\
\text { próbki }\end{array}$ & $\begin{array}{c}\text { Wytrzymałość na } \\
\text { rozciąganie przy } \\
\text { rozłupywaniu } \\
\text { [MPa] }\end{array}$ & $\begin{array}{c}\text { Wytrzymałość na } \\
\text { rozciąganie przy } \\
\text { zginaniu } \\
\text { [MPa] }\end{array}$ \\
\hline \multirow{3}{*}{ DS } & 1 & 1 & $\mathrm{BC}$ & 3,7 & 5,6 \\
\cline { 2 - 6 } & 2 & 1 & $\mathrm{BC}$ & 3,8 & 5,7 \\
\cline { 2 - 6 } & 3 & 1 & $\mathrm{BC}$ & 4,0 & 6,0 \\
\hline
\end{tabular}

\section{Wyniki nośności}

Nośność nawierzchni lotniskowych może być wyrażana wskaźnikiem PCN lub dopuszczalną liczbą operacji lotniczych. W obydwu przypadkach istotną rolę odgrywa liczba dopuszczalnych powtórzeń obciążenia N, która bezpośrednio wpływa na wartość nośności. Należy zwrócić uwagę na fakt, iż liczba powtórzeń obciążenia N jest liczbą ograniczoną. Liczba dopuszczalnych powtórzeń obliczana jest $\mathrm{w}$ zależności od przyjętego modelu obliczeniowego ocenianej konstrukcji nawierzchni lotniskowej. Dla nawierzchni sztywnych, wykonanych $\mathrm{z}$ betonu cementowego, stosuje się następującą formułę wynikającą $\mathrm{z}$ kryterium dopuszczalnych naprężeń [1]:

$$
N=\left[\frac{f_{z g}}{\sigma} \times\left(\frac{E}{30000}\right)^{1.3}\right]^{(1 / 0.233)} \times 10^{4}
$$

gdzie:

$N$ - liczba dopuszczalnych powtórzeń obciążenia,

$f_{z g}$ - wytrzymałość betonu na zginanie [MPa],

$\sigma$ - naprężenia rozciągające przy zginaniu wyznaczone w dolnej części płyty betonowej [MPa],

$E$ - moduł sprężystości betonu [MPa].

Poniżej, w tabeli 5 przedstawiono przykładowe wyniki końcowe z przeprowadzonego badania nośności badanej nawierzchni lotniskowej drogi startowej jednego z obiektów lotniskowych będących w eksploatacji. 
Mariusz Wesołowski, Piotr Barszcz, Krzysztof Blacha

Tabela 5. Wyniki badania nośności nawierzchni lotniskowej drogi startowej

\begin{tabular}{|c|c|c|}
\hline EFL & Wskaźnik nośności PCN & $\begin{array}{c}\text { Całkowita liczba } \\
\text { operacji lotniczych }\end{array}$ \\
\hline DS & $57 /$ R/A/W/T & 19000 \\
\hline
\end{tabular}

\section{Podsumowanie}

Od stanu nośności konstrukcji nawierzchni lotniskowych bezpośrednio zależy bezpieczeństwo wykonywania operacji lotniczych przez statki powietrzne. Przedstawiona $\mathrm{w}$ artykule metoda oceny nośności nawierzchni lotniskowych (ACN-PCN) jest metodą nieniszczącą, która umożliwia klasyfikację nośności nawierzchni na podstawie wyników badań reologicznych materiału warstw i tym samym precyzyjne prognozowanie czasu eksploatacyjnego nawierzchni przy znanych prognozach naziemnego ruchu lotniczego statków powietrznych.

Natomiast kompleksowa analiza stanu nośności ocenianych konstrukcji nawierzchni lotniskowych jest bardzo złożona, ponieważ jej końcowy wynik uzależniony jest nie tylko od obciążeń samolotów, ale i od innych czynników zewnętrznych (czynniki atmosferyczne, liczba operacji lotniczych, wytrzymałość betonu na rozciąganie przy zginaniu, przekrój konstrukcyjny nawierzchni, stan nośności podłoża gruntowego). Zasadniczym problemem przy wymiarowaniu nawierzchni lotniskowych jest przyjęcie właściwego modelu obliczeniowego konstrukcji, który pod wpływem działania obciążenia będzie się zachowywał w sposób zgodny z zachowaniem się rzeczywistych warstw analizowanego układu. Do wyrażenia charakteru oddziaływania statku powietrznego na nawierzchnię sztywną (sprężystą) stosuje się model obliczeniowy płyty o skończonych wymiarach w planie położonej na podłożu typu Winklera, który został opracowany przez Westergarda. W artykule przedstawiono przykładowe wyniki badań nośności przeprowadzonych na jednym $\mathrm{z}$ obiektów lotniskowych eksploatowanych w naszym kraju.

\section{Literatura}

[1] Blacha K., Wesołowski M.: Zależność wskaźnika nośności PCN od liczby operacji lotniczych przy określaniu nośności konstrukcji nawierzchni lotniskowych metodą ACN-PCN, Logistyka nr 6/2014.

[2] Blacha K., Wesołowski M.: Analiza stanu nośności układu sztywnego konstrukcji nawierzchni lotniskowej według założeń metody ACN-PCN, Logistyka nr 6/2015.

[3] Jemielita G., Szcześniak W.: Sposoby modelowania podłoża, Praca poglądowa, Instytut Mechaniki Konstrukcji Inżynierskich.

[4] Nita P.: Budowa i utrzymanie nawierzchni lotniskowych' WKt, Warszawa 1999, 2008.

[5] Nita P.: Betonowe nawierzchnie lotniskowe. Teoria i wymiarowanie konstrukcyjne, Wydawnictwo Instytutu Technicznego Wojsk Lotniczych, Warszawa, 2005. 
Influence of the condition of the airfield pavement structures on the operation... Wptyw stanu nośności konstrukcji nawierzchni lotniskowych na bezpieczeństwo...

[6] Szydło A.: Nawierzchnie drogowe $\mathrm{z}$ betonu cementowego, Teoria, Wymiarowanie, Realizacja, Polski Cement Sp. z o.o., Kraków 2004.

[7] Wesołowski M.: Nośność mobilnych pokryć kompozytowych stosowanych do odbudowy nawierzchni lotniskowych, Rozprawa doktorska, WAT, Warszawa 2012.

[8] ICAO, Aerodrome Design Manual, Part 3, Pavements, 1983.

[9] NO-17-A500:2016 Nawierzchnie lotniskowe i drogowe - Badania nośności.

[10] prNO-17-A503 Nawierzchnie lotniskowe - Naturalne nawierzchnie lotniskowe - Badania nośności.

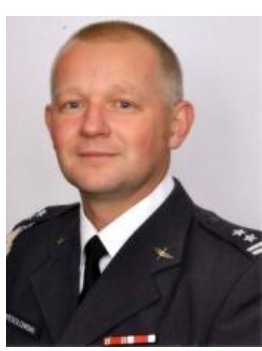

Pptk dr inz. Mariusz Wesolowski, absolwent Wojskowej Akademii Technicznej i Politechniki Warszawskiej. Kierownik Zaktadu Lotniskowego w Instytucie Technicznym Wojsk Lotniczych. Specjalizuje się w projektowaniu, budowie i ocenie stanu technicznego konstrukcji nawierzchni lotniskowych (Udziat 35\%).

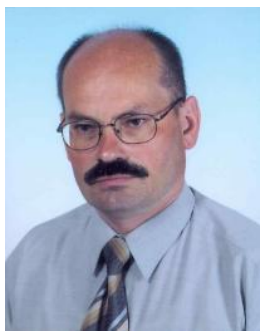

Dr inz. Piotr Barszcz, absolwent Wojskowej Akademii Technicznej. Adiunkt $w$ Instytucie Technicznym Wojsk Lotniczych. Specjalizuje się w tematyce korozji, niezawodności, bezpieczeństwa i eksploatacji statków powietrznych. Uczestniczy $w$ pracach majacych na celu opracowanie $i$ wdrożenie do eksploatacji systemu zarzadzania nawierzchniami lotniskowymi (Udziat 30\%).

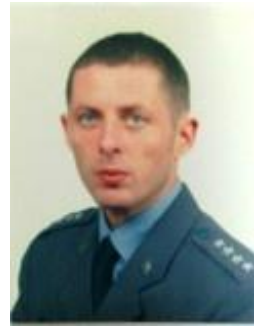

Kpt. mgr inz. Krzysztof Blacha, absolwent Wydziału Inżynierii Wojskowej Wyższej Szkoty Oficerskiej Wojsk Ladowych $i$ Wydziatu Inżynierii Ladowej i Geodezji Wojskowej Akademii Technicznej. Asystent w Zakladzie Lotniskowym w Instytucie Technicznym Wojsk Lotniczych. Specjalizuje sie $w$ projektowaniu, budowie $i$ ocenie stanu technicznego konstrukcji nawierzchni lotniskowych (Udziat 35\%). 